\title{
$\frac{\mathrm{ca}}{50 \mathrm{~d}}$
}
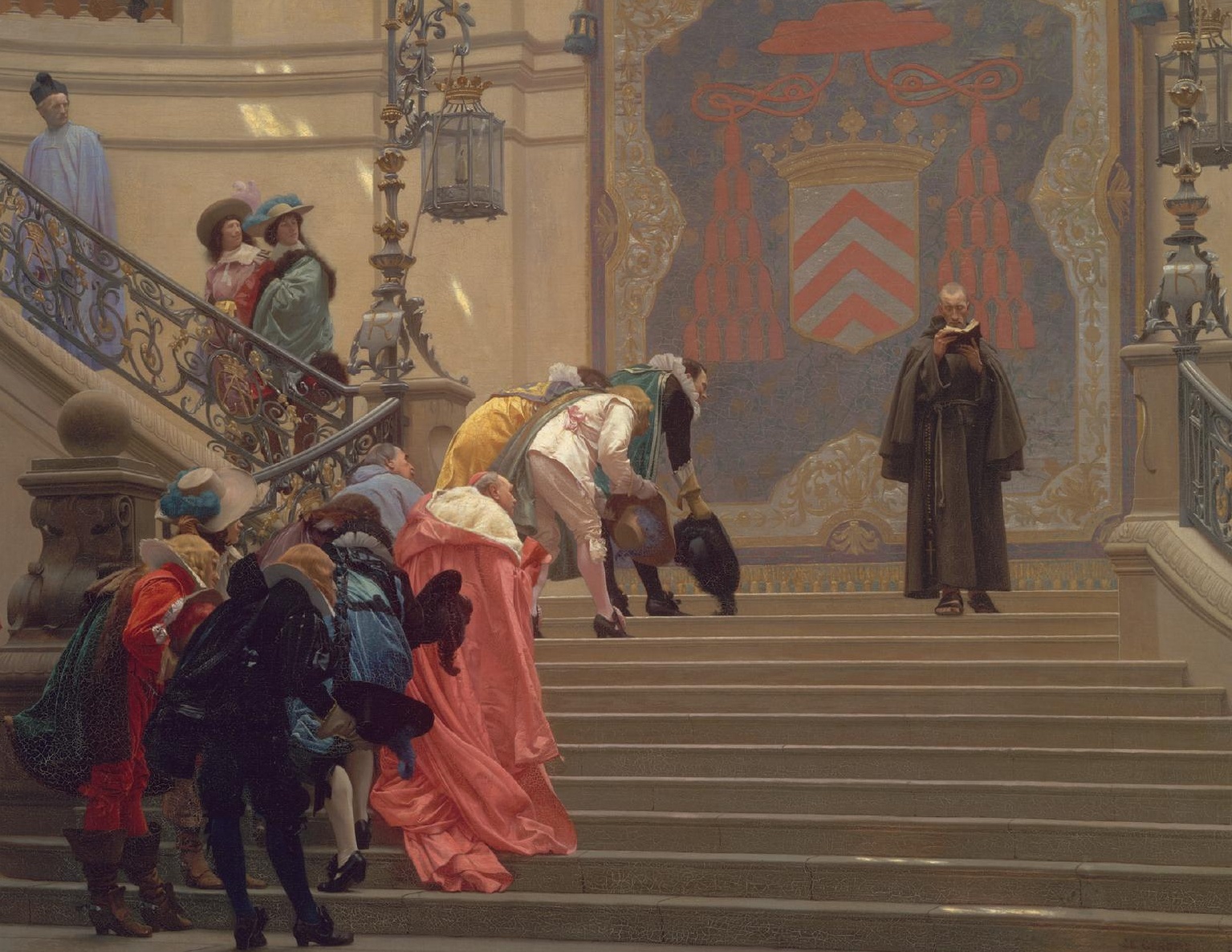

\section{THE POLITICS OF}

RELIGION IN EARLY

MODERN FRANCE

JOSEPH BERGIN 
THE POLITICS OF RELIGION IN EARLY MODERN FRANCE 



\section{THE POLITICS OF RELIGION IN EARLY MODERN FRANCE \\ JOSEPH BERGIN}


Copyright (C) 2014 Joseph Bergin

All rights reserved. This book may not be reproduced in whole or in part, in any form (beyond that copying permitted by Sections 107 and 108 of the U.S. Copyright Law and except by reviewers for the public press) without written permission from the publishers.

For information about this and other Yale University Press publications, please contact: U.S. Office: sales.press@yale.edu www.yalebooks.com

Europe Office: sales@yaleup.co.uk www.yalebooks.co.uk

Typeset in Minion Pro by IDSUK (DataConnection) Ltd

Printed in Great Britain by TJ International Ltd, Padstow, Cornwall

Library of Congress Cataloging-in-Publication Data

Bergin, Joseph, 1948

The politics of religion in early modern France/Joseph Bergin. pages $\mathrm{cm}$

Includes bibliographical references.

ISBN 978-0-300-20769-9 (cloth: alkaline paper)

1. Church and state-France-History-17th century. 2. Christianity and politicsFrance-History-17th century. 3. Catholic Church-France-History-17th century.

4. Protestantism-France-History-17th century. 5. France-Politics and government17th century. 6. France-Religion. 7. France-Church history-17th century. I. Title. BR845.B4337 2014

$322 \cdot .1094409032-\mathrm{dc} 23$

A catalogue record for this book is available from the British Library.

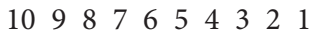


In memory of Bridget (1913-91) and Cornelius (1914-96) Bergin 
